\title{
Promoting Self-Determination for Transition-Age Youth: Views of High School General and Special Educators
}

ERIK W. CARTER

University of Wisconsin-Madison

\section{KATHLEEN L. LANE}

Vanderbilt University

\section{MELINDA R. PIERSON}

KRISTIN K. STANG

California State University-Fullerton

ABStRACT: Recent developments in policy and practice have emphasized the importance of promoting self-determination and supporting access to the general curriculum for youth with disabilities. To understand how these trends align, we examined the efforts of 340 general and special educators to promote student self-determination in high school classrooms. Educators attached considerable importance to providing instruction in skills related to self-determination and reported addressing these skills with moderate to high frequency in their classrooms. Although opportunities for students with disabilities to learn skills that promote self-determination were reported to be available across the curriculum, there were some differences across teachers and curricular area. We discuss avenues for promoting student self-determination within the general curriculum, as well as offer recommendations for future research.

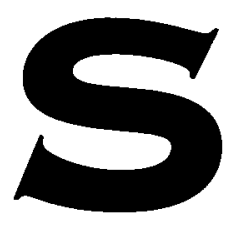

ubstantial efforts have been directed toward ensuring that transition-age youth with disabilities acquire the skills, experiences, supports, and linkages needed to attain important life outcomes after leaving high school (Alwell \& Cobb, 2006). Indeed, transition planning is now firmly established as a critical component of educational programming for youth with disabilities. The Individuals With Disabilities Education Improvement Act of 2004 (IDEA) mandates that schools make coordinated efforts to facilitate students' access to an array of postschool activities, including integrated employment, postsecondary education and training, community participation, and independent living. But equally important are efforts to ensure that youth are equipped to direct those 
activities, align the activities with their personal goals, advocate for their preferences and needs, make informed choices, decide for themselves how they will achieve their goals, and assume responsibility for their own actions. This capacity to steer one's own life in personally meaningful ways and valued directions often is referred to as selfdetermination (Field, Martin, Miller, Ward, \& Wehmeyer, 1998).

In addition to being associated with improved quality of life (Lachapelle et al., 2005; Wehmeyer \& Schwartz, 1998), self-determination also may be a key factor influencing the extent to which youth attain important postschool outcomes (Wehmeyer \& Palmer, 2003; Wehmeyer \& Schwartz, 1997). As a result, increasing the capacity of youth with disabilities to engage in self-determined behavior has assumed a more prominent role in discussions of transition services and supports for youth with disabilities (Eisenman, 2007; Field \& Hoffman, 2002; Field, Sarver, \& Shaw, 2003; Lane \& Carter, 2006). Research indicates that special educators already place high value on promoting self-determination (Agran, Snow, \& Swaner, 1999; Mason, Field, \& Sawilosky, 2004; Thoma, Nathanson, Baker, \& Tamura, 2002); and, increasingly, these teachers report focusing instructional efforts toward equipping students with the skills and opportunities they need to become more self-determined (Carter, Lane, Pierson, \& Glaeser, 2006; Zhang, Wehmeyer, \& Chen, 2005). In a national survey of secondary special educators, Wehmeyer, Agran, and Hughes (2000) found that more than two thirds of teachers indicated that some or all of their students had educational goals addressing self-determination on their individualized education program (IEP) or individualized transition plan (ITP). Moreover, the majority of these special educators reported that providing instruction in each of seven component elements of self-determination (e.g., decision making, goal setting, self-management) was very important. Further evidence of the high value placed on promoting self-determination is apparent in the plethora of available curricula (Bremer, Kachgal, \& Schoeller, 2003; Malian \& Nevin, 2002; Wehmeyer \& Field, 2007) and the incorporation of component elements of self-determination in educator standards (e.g., Council for Exceptional Children, 2003; National Board for Professional Teaching Standards, 1999).

Research suggests, however, that many youth with disabilities lack the knowledge, skills, and beliefs that could enhance their self-determination (e.g., Cameto, Levine, Wagner, \& Marder, 2003; Houchins, 2002; Mithaug, Campeau, \& Wolman, 2003; Zhang, 2001). For example, Carter et al. (2006) evaluated the capacities of high school students with high incidence disabilities to engage in self-determined behavior and found that youth with emotional disturbance were judged by their parents and special educators to have diminished skills in this area. Furthermore, lower levels of self-determination are apparent in the limited contributions youth with disabilities often make to educational planning (Martin et al., 2006), as well as evidenced in interviews with youth themselves (Kortering, Braziel, \& Tompkins, 2002; Trainor, 2005; Whitney-Thomas \& Moloney, 2001). Despite broad agreement concerning the importance of promoting self-determination, it is clear that many youth with disabilities lack the critical skills that can enhance their self-determination.

At the same time, recent legislative and policy initiatives are shifting the contexts within which students with disabilities spend their school day, as well as the standards and curricular content in which students are expected to receive instruction. IDEA and the No Child Left Behind Act of 2001 (NCLB) require schools to ensure that students with disabilities access the same rigorous, relevant curriculum as their peers without disabilities. This emphasis on promoting access to the general curriculum raises the following important questions about where and how educators should deliver transition-related services and supports, as well as the contexts within which youth with disabilities are to be equipped with the skills and opportunities they need to become self-determined:

- Is providing instruction relared to self-determination compatible with the general curriculum?

- To what extent do students have opportunities to learn and apply these skills in general education classrooms? 
- Is instruction in self-determination best addressed in self-contained, specialized, or community-based instructional settings?

Although some researchers and policy makers have expressed concern about whether opportunities for promoting self-determination might be less available within inclusive classrooms (e.g., Kochhar-Bryant \& Bassett, 2002; Zhang, 2001), others have identified the general curriculum as a particularly promising context for promoting selfdetermination among youth with disabilities (Eisenman, 2007; Mason et al., 2004; Test et al., 2004; Wehmeyer, Field, Doren, Jones, \& Mason, 2004). Increasingly, researchers are advocating for more deliberate infusion of self-determination instruction into the general curriculum.

\section{Despite broad agreement concerning} the importance of promoting selfdetermination, it is clear that many youth with disabilities lack the critical skills that

\section{can enhance their self-determination.}

If general education classrooms are emerging as the primary instructional context for increasing numbers of students with disabilities (U.S. Department of Education, 2006), it is essential to understand the views of general educators regarding promoting self-determination in these settings. As a field, it is important to determine the extent to which general educators value self-determination as an instructional priority. Given increasing demands placed on teachers to cover an increasingly diversified curriculum (Lane, Wehby, \& Robertson, 2007), other priorities may contend for instructional time. Because instructional decisions can be influenced by multiple factors, it also is essential to know whether general educators actually allocate instructional time to this domain. Previous research has documented substantial discrepancies in the extent to which special educators say they value self-determination and the extent to which they actually make efforts to promote it in their classrooms (Agran et al., 1999; Grigal, Neubert, Moon, \& Graham, 2003; Wehmeyer et al., 2000). Such discrepancies may be attributable to multiple factors, including the need for additional training, competing instrucrional priorities, availability of needed resources, and degree of administrator support.

Previous research, however, has not explored the extent to which teaching skills that promote self-determination is valued and addressed by general educators. Grigal et al. (2003) surveyed 131 general education high school teachers and found that they were somewhat less familiar with the concept of self-determination than were special educators. However, the researchers did not report the extent to which these teachers actually devoted instructional time to promoting self-determination in their classrooms. In another survey of educators' perceptions and instructional practices related to self-determination, Mason et al. (2004) found that educators generally perceived self-determination to be very important, with the majority saying they taught self-management and goal setting skills to their students. However, findings for the more than 60 general educators participating in this study were not disaggregated from those of special educators. Additional research is needed to address several existing gaps in this literature.

First, it is important to understand whether general and special educators share similar views on promoting self-determination. Because high school students typically rotate between multiple teachers and classrooms throughout each school day, marked differences in instructional priorities could hinder consistency in educational programming. Shared instructional goals, however, might translate into increased opportunities for students to learn and practice self-determined behavior across the school day. Research in areas such as secondary inclusion (Carter \& Hughes, 2006); social/behavioral expectations (Lane, Pierson, \& Givner, 2004); and mathematics instructional/assessment practices (Maccini \& Gagnon, 2006), however, suggest that general and special educators at the secondary level may hold divergent views in some instructional areas.

Second, high schools typically offer a diverse array of curricular options, some of which may be presumed to hold greater opportunities for enabling students to develop skills related to selfdetermination. Although $70 \%$ of youth with disabilities are enrolled in one or more core academic general education courses (e.g., language arts, 
math, science, social studies), an even greater percentage $(83 \%)$ of youth with disabilities are enrolled in at least one elective course (Wagner, Newman, \& Cameto, 2004). Despite calls for infusing self-determination in the general curriculum, there is little discussion of where within the curriculum such instruction might be most relevant and likely to be available. Although core academic courses may be perceived to offer little time to address instructional domains-such as self-determination-not directly assessed on high-stakes tests, several researchers have articulated how these skills might still be addressed in such classes (e.g., Eisenman \& Tascione, 2002; Palmer, Wehmeyer, Gipson, \& Agran, 2004). Research exploring similarities and differences in opportunities across classroom contexts could provide valuable information to assist practitioners with scheduling, planning, and instructional design efforts.

This study examined educators' efforts to promote self-determination in high school classrooms. Specifically, we sought to answer the following questions:

1. How do high school teachers evaluate the importance of providing instruction in each of seven self-determination skill domains?

2. To what extent do high school teachers actually deliver instruction in each of these domains?

3. Do general and special educators share similar priorities in the area of self-determination?

4. Are similar opportunities for receiving selfdetermination instruction available across diverse curricular areas?

Given the increasingly prominent role of self-determination within the special education literature during the past decade, we hyporhesized that special educators would attach greater importance to providing instruction across all areas of self-determination relative to general educators and allocate greater amounts of instructional time to these areas. We also anticipated that somewhat fewer opportunities for receiving self-determination instruction would be available in core academic general education classes.

\section{METHOD}

\section{PARTICIPANTS}

Participants were 340 educators working within eight ethnically and economically diverse high schools. The majority was female $(57.2 \%)$ and Caucasian $(79.3 \%)$, closely mirroring the demographic makeup of the secondary educator workforce in the state. These educators were fairly experienced, reporting an average of 12.8 years ( $S D=11.2$ years $)$ of teaching experience with most $(57.7 \%)$ holding a graduate degree. Three quarters $(n=255)$ of these participants were general educators; $16.2 \%(n=55)$ were special educators serving students in resource or self-contained classrooms; and the remaining $8.8 \%(n=30)$ reported other program responsibilities within their schools (e.g., related services, English language learner support staff). Among the educators reporting which courses they taught at the time of the study, $77.3 \%$ exclusively taught academic classes (i.e., language arts, mathematics, sciences, social sciences, humanities, foreign language); $9.8 \%$ exclusively taught elective classes (i.e., related arts, physical education, health, vocational); and $12.9 \%$ taught both types of classes. Table 1 provides additional participant demographics.

\section{SCHOOLS}

Participants in this study worked at eight high schools within three school districts in a western state. These districts ranged in size from 6,193 to 30,901 students $(M=21,283)$ and served both urban and suburban communities. Student enrollment at the high schools averaged 1,417 students $(S D=1,103)$. Mean ethnicity of students across all schools was $45.8 \%$ Caucasian (range, $18.3 \%$ $77.5 \%$ ); $41.7 \%$ Hispanic (range, 13.1\%-68.4\%); $6.5 \%$ Asian American (range, 1.0\%-14.3\%); 2.4\% African American (range, 1.3\%-4.3\%); and $3.6 \%$ other ethnicities (range, $0.5 \%-9.5 \%$ ). The percentage of students receiving free or reduced lunch rates across schools averaged $26.8 \%$ (range, $7.3 \%-53.7 \%$ ). Although these schools were representative of other secondary schools nationally with regard to school size and poverty rate, Hispanic students were overrepresented and Caucasian and African American students were under- 


\begin{tabular}{|c|c|c|c|c|c|c|}
\hline & \multicolumn{2}{|c|}{$\begin{array}{l}\text { General Educators } \\
\mathrm{N}=255\end{array}$} & \multicolumn{2}{|c|}{$\begin{array}{c}\text { Special Educators } \\
\qquad \mathrm{N}=55\end{array}$} & \multicolumn{2}{|c|}{$\begin{array}{l}\text { All Educators } \\
\qquad \mathrm{N}=340\end{array}$} \\
\hline & $\%$ & $\mathrm{n}$ & $\%$ & $\mathrm{n}$ & $\%$ & $\mathrm{n}$ \\
\hline \multicolumn{7}{|l|}{ Gender } \\
\hline Female & 55.0 & 138 & 61.8 & 34 & 57.2 & 190 \\
\hline Male & 45.0 & 113 & 36.4 & 20 & 42.8 & 142 \\
\hline \multicolumn{7}{|l|}{ Ethnicity } \\
\hline African American & 1.2 & 3 & 10.9 & 6 & 2.6 & 9 \\
\hline Asian American & 4.0 & 10 & 0.0 & 0 & 3.3 & 11 \\
\hline Caucasian & 79.8 & 197 & 74.5 & 41 & 79.3 & 261 \\
\hline Hispanic & 8.5 & 21 & 7.3 & 4 & 8.2 & 27 \\
\hline Native American & 1.2 & 3 & 1.8 & 1 & 1.2 & 4 \\
\hline Other ethnicities & 5.3 & 13 & 5.5 & 3 & 5.2 & 17 \\
\hline \multicolumn{7}{|l|}{ Teaching experience } \\
\hline 1 to 5 years & 32.1 & 75 & 44.0 & 22 & 32.6 & 101 \\
\hline 6 to 10 years & 29.1 & 68 & 26.0 & 13 & 27.7 & 86 \\
\hline 11 to 15 years & 7.3 & 17 & 8.0 & 4 & 8.4 & 26 \\
\hline 16 to 20 years & 5.6 & 13 & 6.0 & 3 & 5.8 & 18 \\
\hline 21 to 25 years & 5.6 & 13 & 2.0 & 1 & 5.5 & 17 \\
\hline 26 or more years & 20.5 & 48 & 14.0 & 7 & 20.0 & 62 \\
\hline \multicolumn{7}{|l|}{ Highest degree } \\
\hline Bachelor's & 42.0 & 107 & 54.5 & 30 & 42.0 & 146 \\
\hline Master's & 51.8 & 132 & 43.6 & 24 & 49.4 & 172 \\
\hline Doctorate & 3.5 & 9 & 1.8 & 1 & 3.2 & 11 \\
\hline
\end{tabular}

Note. Percentages are based on the number of participants who provided information for each item.

represented in the school sample (Snyder, Dillow, \& Hoffman, 2007).

\section{INSTRUMENT}

Educators rated each of seven instructional domains associated with self-determination-choice making, decision making, goal setting and attainment, problem solving, self-advocacy and leadership skills, self-awareness and self-knowledge, and self-management and self-regulation skills-along two dimensions. First, teachers rated the importance of teaching each skill domain relative to other instructional priorities in their classroom. Ratings were provided along a 6-point Likert-type scale ranging from low (1) to high (6). Second, teachers rated how often they taught each skill in their classroom. Ratings were provided on a 6point Likert-type scale ranging from never (1) to often (6). Self-determination instructional domains were drawn from Wehmeyer et al.'s (2000) national survey of special education teacher's promotion of self-determination. Each item was accompanied by brief examples of instructional activities that might compose the domain. For example, "teaching students to monitor and evaluate their own behavior, select and provide their own reinforcement, set their own schedule, and to self-direct learning through strategies like self-instruction" was listed adjacent to "self-management and self-regulation skills." There was no specific reference to students' disability status on the questionnaire; rather, respondents simply rated items in relation to students in their own classrooms. To retain the ability to make comparisons across studies, we used the same item wording, examples, and scale anchors as those included on the Wehmeyer et al. survey. However, we 
added the second response dimension (i.e., how often instruction was provided in each domain) to assess the amount of time educators devoted to each area of self-determination. The instrument had strong internal consistency with coefficient alpha reliabilities of 0.86 and 0.83 for the importance and actual instruction scales. In addition, we collected basic demographic information (i.e., gender, ethnicity, years of teaching experience, credentials held), as well as information about current instructional responsibilities (i.e., grade level; general education, special education, or other program area; and courses taught during the current semester).

\section{PROCEDURES}

We collected these data as part of a larger investigation of educators' perceptions of instructional priorities for students in their classrooms. We randomly selected eight school districts from among all districts in the southern region of the state. Two districts declined participation, citing competing commitments that would make the timing of the study difficult. Of the six participating districts, three were elementary districts (Grades K-6 or $\mathrm{K}-8$ ), comprising exclusively elementary and middle schools. Thus, three unified school districts (Grades $\mathrm{K}-12$ ) participated in this aspect of the project.

Of the 11 high schools within these three districts, eight principals agreed to participate in the study. We attended schoolwide faculty meetings at participating schools throughout the spring semester to provide educators with a verbal and written overview of the research study, obtain consent to participate, and distribute questionnaires. The project was not framed as a study focused on students with disabilities, nor were students with disabilities listed as the referents for any questionnaire items. Educators completed questionnaires individually and anonymously and placed them in a sealed, slotted box. Approximate completion time for the questionnaire was 15 to $20 \mathrm{~min}$. One principal requested a departure from these administration procedures. At this school, educators received the questionnaires from their principal, completed them independently on their own time, and returned them to a sealed box in the school office at their conve- nience. The overall participation rate for the schools averaged $76.2 \%(S D=16.0 \%$; range, $58.9 \%-100 \%)$.

Four research associates entered the data, with fidelity of data entry assessed by an additional research associate for $25 \%$ of the questionnaires. Any data entry errors were noted and corrected. Of the 348 questionnaires obtained using these procedures, we excluded 8 from the analyses because the self-determination section of the questionnaire had not been completed.

\section{DATA ANALYSIS}

We used descriptive and correlational statistics to summarize ratings of importance and actual instruction across all respondents. Repeated measures of analyses of variance (ANOVAs) with simple contrasts compared educators' ratings of importance and actual instruction across the selfdetermination domains. We adjusted alpha levels to .002 using the Bonferonni correction procedure to address the number of comparisons conducted. We then computed one-way fixed-effects multivariate analyses of variance (MANOVAs) using the general linear model to evaluate differences in ratings of importance and actual instruction associated with teacher type (general educator versus special educator) and curricular area (academic classes versus elective classes versus both types of class). Curricular areas followed categories outlined in Wagner, Newman, Cameto, Levine, and Marder (2003). For each MANOVA, we treated the subgroup membership (teacher type or curricular area) as a fixed-effects factor. Dependent variables were the item level responses: choice making, decision making, goal setting/attainment, problem solving, self-advocacy/leadership skills, self-awareness/self-knowledge, and self-management/self-regulation skills. We tested the multivariate analyses using Wilks's Lambda $(\Lambda)$ criterion, although other criteria (i.e., Pillai's trace, Roy's maximum root) produced the same decisions regarding statistical significance. ANOVAs were corrected for Type I error rate using the Bonferonni adjustment based on the number of ANOVAs computed subsequent to each MANOVA, producing a required significance level of .007. Multiple comparisons were not necessary for the comparisons between gen- 
eral and special educators given that each comparison involved only two groups (Kleinbaum, Kupper, Muller, \& Nizam, 1998). Tukey honest significant difference (HSD) comparisons were used to contrast groups constituting the curricular focus area. Finally, we used descriptive statistics to summarize ratings of actual instruction in the seven domains by course type (e.g., language arts, math, social studies).

\section{RESULTS}

\section{HOW DO TEACHERS VIEW THE}

\section{IMPORTANCE OF PROVIDING}

\section{INSTRUCTION IN SELF-DETERMINATION?}

Educators generally attributed moderate to high levels of importance to each of the seven component elements of self-determination (see Table 2), with all means exceeding the mid-point of the scale. More than two thirds of educators rated problem solving, self-management/self-regulation, decision making, and goal setting/attainment as being very important (i.e., ratings of 5 or 6 ) relative to other instructional priorities in their classroom. A one-way repeated measures ANOVA revealed significant differences in ratings of importance among the seven domains, Wilks's $\Lambda=$ $.71, F(6,330)=21.87, p<.001, \eta^{2}=.284$. Follow-up contrasts indicated that problem solving was rated significantly higher than all other domains; self-management/self-regulation and decision making were rated significantly higher than choice making, self-advocacy/leadership, and selfawareness/self-knowledge; and goal setting was rated significantly higher than self-advocacy/leadership and self-awareness/self-knowledge. The educators viewed all other domains as equally important instructional priorities.

\section{How OfTEN Do TeACHERS PROVIDE INSTRUCTION IN SELF-DETERMINATION?}

Educators reported that they sometimes to often taught each of the seven skills associated with enhanced self-determination in their classrooms. Problem solving was the only domain that more than two thirds of educators reported frequently teaching (i.e., ratings of 5 or 6 ) in their classroom. A one-way repeated measures ANOVA yielded significant differences in ratings of instructional time devoted to the seven skill domains, Wilks's $\Lambda=.72, F(6,326)=21.67, p<.001, \eta^{2}=.285$. Follow-up contrasts indicated that problem solving was taught significantly more often than all other domains; self-advocacy/leadership was taught significantly less than all other domains; and self-management/self-regulation was taught significantly more often than goal setting. All other domains received similar emphasis with regard to instructional time.

\section{WHAT IS THE RELATION BETWEEN IMPORTANCE OF SELF-DETERMINATION AND ACTUAL INSTRUCTION?}

Overall, we identified a strong relation between educators' ratings of domain importance and the instructional time they devoted to these skill areas. We found significant positive correlations for all seven items: choice making $(r=.75$, $p<.001)$; decision making $(r=.74, p<.001)$; problem solving $(r=.76, p<.001)$; goal setting/attainment $(r=.72, p<.001)$; self-advocacy/leadership $(r=.75, p<.001)$; self-management/self-regulation $(r=.71, p<.001)$; and self-awareness/self-knowledge $(r=.72, p<.001)$.

\section{DO GENERAL AND SPECIAL EDUCATORS SHARE SIMILAR PRIORITIES RELATED TO SELF-DETERMINATION?}

We examined the extent to which general and special educators held different views concerning the importance of providing instruction in selfdetermination skills within their classrooms. A one-way MANOVA indicated a significant multivariate effect for program type, Wilks's $\Lambda=0.95$, $F(7,298)=2.18, p=.04$, accounting for $5 \%$ of the explained variance. Follow-up ANOVAs showed a group effect for self-advocacy/leadership skills, $F(1,304)=10.36, p<.001$, and self-awareness/self-knowledge skills, $F(1,304)=8.52$, $p<.004$. Specifically, special educators rated providing instruction in these areas as significantly more important than did general educators. There were no significant differences between the general and special educators on the remaining items when using the 0.007 criterion (see Table 3 for group means). 
Overall Ratings of Skill Importance and Reported Instruction

\begin{tabular}{|c|c|c|c|c|c|c|c|c|}
\hline \multirow[b]{2}{*}{ Domain } & \multicolumn{3}{|c|}{ Importance (\% ranking) } & \multirow[b]{2}{*}{$M(S D)$} & \multicolumn{3}{|c|}{ Instruction (\% ranking) } & \multirow[b]{2}{*}{$\mathrm{M}(\mathrm{SD})$} \\
\hline & $\begin{array}{l}1 \text { or } 2 \\
\text { Low }\end{array}$ & $\begin{array}{c}3 \text { or } 4 \\
\text { Moderate }\end{array}$ & $\begin{array}{c}5 \text { or } 6 \\
\text { High }\end{array}$ & & $\begin{array}{l}1 \text { or } 2 \\
\text { Never }\end{array}$ & $\begin{array}{c}3 \text { or } 4 \\
\text { Sometimes }\end{array}$ & $\begin{array}{l}5 \text { or } 6 \\
\text { Often }\end{array}$ & \\
\hline Problem solving & $1.2 \%$ & $20.0 \%$ & $78.8 \%$ & $5.16(0.99)$ & $3.3 \%$ & $29.4 \%$ & $67.3 \%$ & $4.86(1.11)$ \\
\hline Self-management & $2.6 \%$ & $29.8 \%$ & $67.6 \%$ & $4.94(1.10)$ & $6.0 \%$ & $42.7 \%$ & $51.3 \%$ & $4.49(1.26)$ \\
\hline Decision making & $3.3 \%$ & $28.4 \%$ & $68.3 \%$ & $4.89(1.09)$ & $7.2 \%$ & $39.7 \%$ & $53.1 \%$ & $4.45(1.25)$ \\
\hline Goal setting & $4.7 \%$ & $28.6 \%$ & $66.7 \%$ & $4.80(1.13)$ & $11.9 \%$ & $41.4 \%$ & $46.7 \%$ & $4.24(1.32)$ \\
\hline Choice making & $3.3 \%$ & $41.2 \%$ & $55.5 \%$ & $4.63(1.10)$ & $6.3 \%$ & $49.6 \%$ & $44.1 \%$ & $4.29(1.24)$ \\
\hline Self-awareness & $5.0 \%$ & $36.3 \%$ & $58.7 \%$ & $4.62(1.17)$ & $9.8 \%$ & $42.9 \%$ & $47.3 \%$ & $4.27(1.29)$ \\
\hline Self-advocacy & $7.4 \%$ & $42.0 \%$ & $50.6 \%$ & $4.44(1.26)$ & $14.3 \%$ & $51.5 \%$ & $34.2 \%$ & $3.97(1.30)$ \\
\hline
\end{tabular}

DO GENERAL AND SPECIAL EDUCATORS

DIFFER IN THE EXTENT TO WHICH

THEY ACTUALLY PROVIDE SKILL

INSTRUCTION IN SKILLS THAT

ENHANCE SELF-DETERMINATION?

The MANOVA comparing how often general and special education teachers taught these skills did not yield a significant multivariate effect, Wilks's $\Lambda=0.97, \mathrm{~F}(7,296)=1.27, \mathrm{p}=0.27$. Therefore, we did interpret univariate ANOVAs.

\section{DO OPPORTUNITIES TO RECEIVE}

INSTRUCTION IN SELF-DETERMINATION

DIFFER ACROSS CURRICULAR AREAS?

We examined whether educators' evaluations of the importance of providing instruction in skills that promote self-determination differ based on whether they teach courses focused on academics, elective, or both. A one-way MANOVA revealed a significant multivariate effect for curricular area, Wilks's $\Lambda=0.92, F(14,608)=1.76, p=.04$, accounting for $8 \%$ of the explained variance. A series of ANOVAs showed a group effect for choice making, $F(2,310)=6.85, p<.001$; decision making, $F(2,310)=6.61, p<.001$; and self-management/self-regulation, $F(2,310)=5.16, p<.006$. Multiple comparisons indicated that the ratings of educators teaching in both academic and elective classes were significantly higher than those of educators exclusively teaching academic classes across all three items. All other items were evaluated similarly (see Table 3).
DOES THE EXTENT TO WHICH EDUCATORS

ACTUALLY PROVIDE SKILL INSTRUCTION

DIFFER DEPENDING ON WHETHER THEY

TEACH ACADEMIC, ELECTIVE, OR BOTH

TYPES OF CLASSES?

Results of a one-way MANOVA indicated a significant multivariate effect for curricular area, Wilks's $\Lambda=0.92, F(14,602)=1.77, p=.04$, accounting for $8 \%$ of the explained variance. A series of ANOVAs revealed a group effect for choice making, $F(2,307)=8.27, p<.001$, and decision making, $F(2,307)=5.23, p<.006$. Follow-up comparisons indicated that the ratings of educators teaching in both academic and elective classes were significantly higher than those of educators exclusively teaching academic classes.

Table 4 displays educators' ratings of actual instruction in each skill domain of self-determination by type of course subject. Ratings of educators teaching humanities classes were consistently higher than those of educators teaching other subjects. Ratings of educators teaching foreign language and science classes were consistently lower than ratings in other subjects. However, there was considerable variability across subjects and area of self-determination.

\section{DISCUSSION}

Increasing access to the general curriculum for students with disabilities has emerged as a central theme of recent legislative and policy initiatives (i.e., IDEA and NCLB). Indeed, educators are 
Ratings of Skill Importance and Reported Instruction by Program Type and Curricular Area

\begin{tabular}{|c|c|c|c|c|c|c|c|}
\hline \multirow[b]{2}{*}{ Domain } & \multicolumn{3}{|c|}{ Program Type } & \multicolumn{4}{|c|}{ Curricular Area } \\
\hline & $\begin{array}{c}\text { General } \\
\text { Education } \\
\mathrm{M}(\mathrm{SD})\end{array}$ & & $\begin{array}{c}\text { Special } \\
\text { Education } \\
\text { M (SD) }\end{array}$ & $\begin{array}{l}\text { Academic } \\
\mathrm{M}(\mathrm{SD})\end{array}$ & & $\begin{array}{c}\text { Both } \\
\mathrm{M}(\mathrm{SD})\end{array}$ & $\begin{array}{l}\text { Elective } \\
\qquad \mathrm{M}(\mathrm{SD})\end{array}$ \\
\hline \multicolumn{8}{|l|}{ Problem solving } \\
\hline Importance & $5.15(1.05)$ & & $5.18(0.77)$ & $5.15(1.00)$ & & $5.17(0.92)$ & $5.13(1.06)$ \\
\hline Instruction & $4.85(1.16)$ & & $4.76(0.96)$ & $4.82(1.08)$ & & $4.97(1.30)$ & $4.88(1.19)$ \\
\hline \multicolumn{8}{|c|}{ Self-management } \\
\hline Importance & $4.86(1.13)$ & & $5.27(0.87)$ & $4.86(1.11)$ & $<$ & $5.44(0.71)$ & $4.84(1.27)^{*}$ \\
\hline Instruction & $4.41(1.28)$ & & $4.76(1.15)$ & $4.42(1.23)$ & & $4.45(1.50)$ & $4.88(1.17)$ \\
\hline \multicolumn{8}{|c|}{ Decision making } \\
\hline Importance & $4.87(1.12)$ & & $5.05(0.89)$ & $4.76(1.12)$ & $<$ & $5.39(0.67)$ & $5.10(1.25)^{*}$ \\
\hline Instruction & $4.44(1.26)$ & & $4.65(0.97)$ & $4.31(1.21)$ & $<$ & $4.74(1.50)$ & $4.90(1.02)^{*}$ \\
\hline \multicolumn{8}{|l|}{ Goal setting } \\
\hline Importance & $4.73(1.17)$ & & $5.05(0.95)$ & $4.71(1.14)$ & & $5.10(1.02)$ & $4.84(1.19)$ \\
\hline Instrucrion & $4.18(1.37)$ & & $4.44(1.10)$ & $4.17(1.31)$ & & $4.23(1.45)$ & $4.32(1.29)$ \\
\hline \multicolumn{8}{|l|}{ Choice making } \\
\hline Importance & $4.57(1.13)$ & & $4.85(0.95)$ & $4.48(1.08)$ & $<$ & $5.12(0.90)$ & $4.81(1.28)^{*}$ \\
\hline Instruction & $4.26(1.25)$ & & $4.42(1.20)$ & $4.10(1.20)$ & $<$ & $4.58(1.41)$ & $4.85(0.99)^{*}$ \\
\hline Self-awareness & & & & & & & . \\
\hline Importance & $4.53(1.19)$ & $<$ & $5.04(0.96)^{*}$ & $4.56(1.10)$ & & $4.98(0.99)$ & $4.55(1.52)$ \\
\hline Instruction & $4.27(1.31)$ & & $4.35(1.14)$ & $4.18(1.25)$ & & $4.42(1.50)$ & $4.66(1.11)$ \\
\hline \multicolumn{8}{|l|}{ Self-advocacy } \\
\hline Importance & $4.35(1.27)$ & $<$ & $4.95(1.06)^{*}$ & $4.35(1.24)$ & & $4.85(1.11)$ & $4.32(1.40)$ \\
\hline Instruction & $3.91(1.30)$ & & $4.31(1.29)$ & $3.90(1.26)$ & & $3.90(1.51)$ & $4.12(1.23)$ \\
\hline
\end{tabular}

${ }^{*} p<.007$.

being called upon to ensure that students with disabilities of all ages progress toward the same state and local curricular standards as their classmates without disabilities, shifting the primary instructional context to the general education classroom for increasing numbers of students (U.S. Department of Education, 2006). As youth with disabilities enter and progress through high school, however, an emphasis on promoting skills and opportunities that enhance student self-determination also becomes more prominent. Recognizing the potential tension between these dual trends, Test et al. (2004) asked, "Can self-determination peacefully co-exist with standards-based reforms and access to the general curriculum?" (p. 408). Our findings suggest an affirmative answer to this question.
This study extends the literature on promoting self-determination in several ways. First, calls to infuse self-determination within the general curriculum have predominantly emerged from among special educators (Chambers et al., 2007; Mason et al., 2004; Wehmeyer et al., 2004) and have presumed that general educators would likely be receptive to this emerging instructional domain. Until now, however, this assumption has remained largely unexplored. We found that general educators attached considerable importance to promoting various component elements of selfdetermination in their classrooms. Specifically, skills such as problem solving, decision making, self-management, and goal setting were judged to be fairly high instructional priorities, cven in relation to other curricular priorities. That general 
TABLE 4

Reported Instruction in Self-Determination Domains by Curricular Area

\begin{tabular}{lccccccc}
\hline $\begin{array}{l}\text { Curricular } \\
\text { Area }\end{array}$ & $\begin{array}{c}\text { Problem } \\
\text { Solving } \\
\mathrm{M}(\mathrm{SD})\end{array}$ & $\begin{array}{c}\text { Sanagement } \\
\mathrm{M}(\mathrm{SD})\end{array}$ & $\begin{array}{c}\text { Decision } \\
\text { Making } \\
\mathrm{M}(\mathrm{SD})\end{array}$ & $\begin{array}{c}\text { Goal } \\
\text { Setting } \\
\mathrm{M}(\mathrm{SD})\end{array}$ & $\begin{array}{c}\text { Choice } \\
\text { Making } \\
\mathrm{M}(\mathrm{SD})\end{array}$ & $\begin{array}{c}\text { Self- } \\
\text { Awareness } \\
\mathrm{M}(\mathrm{SD})\end{array}$ & $\begin{array}{c}\text { Self- } \\
\text { Advocacy } \\
\mathrm{M}(\mathrm{SD})\end{array}$ \\
\hline $\begin{array}{l}\text { Humanities } \\
\text { Language }\end{array}$ & $5.67(0.52)$ & $5.33(0.82)$ & $5.83(0.41)$ & $5.33(0.82)$ & $5.00(1.10)$ & $5.33(0.82)$ & $5.17(0.75)$ \\
Arts & $4.69(1.07)$ & $4.74(1.16)$ & $4.51(1.16)$ & $4.41(1.30)$ & $4.57(1.07)$ & $4.56(1.19)$ & $4.21(1.17)$ \\
Mathematics & $5.23(0.95)$ & $4.63(1.11)$ & $4.33(1.16)$ & $4.26(1.21)$ & $3.99(1.19)$ & $4.32(1.02)$ & $3.82(1.32)$ \\
Sciences & $4.97(1.04)$ & $4.45(1.17)$ & $4.34(1.21)$ & $3.97(1.31)$ & $3.89(1.22)$ & $3.87(1.37)$ & $3.69(1.29)$ \\
Social & & & & & & & \\
Studies & $4.71(1.05)$ & $4.36(1.43)$ & $4.67(1.11)$ & $4.09(1.26)$ & $4.53(1.21)$ & $4.21(1.31)$ & $4.26(1.26)$ \\
Foreign & & & & & & & \\
Language & $4.29(1.20)$ & $4.21(1.35)$ & $3.83(1.40)$ & $4.13(1.23)$ & $4.33(1.24)$ & $3.83(1.09)$ & $3.88(1.62)$ \\
Physical & & & & & & & \\
Education & $4.83(0.97)$ & $4.66(1.17)$ & $4.97(1.09)$ & $4.45(1.09)$ & $4.66(1.11)$ & $4.48(1.18)$ & $4.14(1.19)$ \\
Related Arts & $4.85(1.49)$ & $4.77(1.34)$ & $4.73(1.49)$ & $4.31(1.69)$ & $4.54(1.33)$ & $4.88(1.31)$ & $4.23(1.45)$ \\
Vocational & $5.14(1.08)$ & $4.73(1.49)$ & $4.86(1.17)$ & $4.36(1.20)$ & $5.05(1.13)$ & $4.36(1.47)$ & $3.82(1.44)$ \\
\hline
\end{tabular}

Note. $1=$ never, $6=$ often.

educators attach considerable value to these instructional domains may bode well for transitionage youth with disabilities whose IEPs or ITPs include self-determination-related goals. These educators may already recognize the importance of such goals and be receptive to adapting or augmenting the curriculum in ways that support acquisition of these skills for their students with disabilities.

Moreover, general educators' perceptions of the importance of teaching self-determination were broadly articulated. As stated previously, we asked participants to evaluate the importance of teaching component skills of self-determination within their classrooms, rather than specifically about the relevance of these skills for students with disabilities. Our findings suggest that general educators may judge self-determination as having an integral place in the curriculum for all students. Thus, promoting self-determination appears to be entirely consistent, rather than incompatible, with the general curriculum, quelling concerns that promoting self-determination may fall outside of the standards-based curriculum. In fact, these component elements already are woven throughout most state and local general curriculum standards (Wehmeyer \&
Field, 2007; Wehmeyer et al., 2004). Future researchers should examine more closely the possibility that educators hold differing views of self-determination as a curricular priority depending on whether or not a student has a disability, as well as the severity of that disability (Wehmeyer et al., 2000).

Second, general and special educators generally converged in their evaluations of the importance of promoting self-determination at the high school level. Although special educators' overall ratings of importance were slightly higher than those of general educators, both attached the highest level of importance to the same three selfdetermination domains-problem solving, selfmanagement, and decision making. Such shared priorities among general and special educators are not always apparent at the high school level, as evidenced in recent studies exploring teacher expectations (Carter \& Hughes, 2006; Lane et al., 2004). Discrepancies in priorities can be a substantial impediment to shared planning and instruction, challenging inclusion efforts and hindering access to the general curriculum. It is promising, therefore, that general and special educators generally align on this aspect of the curriculum. 
Some differences were noted, however, in the areas of self-advocacy (i.e., knowing and standing up for oneself and one's rights) and self-awareness (i.e., knowing and applying one's own strengths, preferences, interests, and limitations). Although these component elements of self-determination appear to be fairly prominent in the special education literature (Test, Fowler, Wood, Brewer, \& Eddy, 2005), they may be valued somewhat less within general education classrooms. Indeed, fewer than half of general educators rated self-advocacy and self-awareness as having high importance in their classrooms. This corroborates Lane et al.'s (2004) findings, that high school general educators placed significantly less emphasis on assertion-related skills as critical to student success in their classroom. Moreover, none of the self-advocacy interventions reviewed in a meta-analysis by Test, Fowler, Brewer, and Wood (2005) had been implemented in general education high school classrooms. Educators may need to seek out supplemental instructional contexts for developing students' capacities for self-advocacy and self-awareness, including educational planning meetings (Martin et al., 2006); student-led support groups (Pocock et al., 2002); or youth leadership forums (Van-Belle, Marks, Martin, \& Chun, 2006).

\section{Although special educators' overall ratings of importance were slightly higher than those of general educators, both attached the highest level of importance to the same three self-determination domains-problem solving, self- management, and decision making.}

Although special educators' ratings of self-determination domain importance in our study generally parallel those obtained in Wehmeyer et al.'s (2000) national study, we documented slightly higher ratings for six of seven instructional domains, with mean score differences ranging from .12 and .59 . These small increases in ratings of importance might be attributed to differences in sampling procedures and population parameters (i.e., the earlier study included a small percentage of middle school teachers and focused primarily on students with intellectual disabilities); however, they may also serve as a potential indicator that self-determination is assuming a more prominent role in the education of transition-age youth with disabilities. Copious articles, books, and curricula have been published over the past decade, elevating self-determination to an integral part of discussions surrounding secondary transition planning and services. Additional research is needed to gauge how teachers are circumventing previously cited barriers to the promotion of selfdetermination (e.g., insufficient training, paucity of curricular and assessment materials, perceptions of limited efficacy).

Third, opportunities for learning and applying skills that enhance self-determination appear to be available across the high school curriculum, including both elective and core academic courses. Unlike previous research (Agran et al., 1999; Thoma et al., 2002; Wehmeyer et al., 2000), we found that the importance educators attached to promoting self-determination was reflected in the amount of instructional time they reported allocating to each area. General and special educators alike reported that they frequently taught component elements of self-determination within a range of curricular areas. These findings offer one indicator of the social validity of self-determination instruction, as devoting instructional time to this instructional domain is a primary indicator of its acceptability and feasibility to educators.

At first glance, our findings may appear to run contrary to parent and student perceptions that youth with disabilities have fairly limited opportunities to become self-determined (Carter et al., 2006; Grigal et al., 2003; Zhang et al., 2005). However, it should be stressed that simply being present in general education classrooms does not guarantee that students are accessing and progressing within the same curriculum. For many students with disabilities, there may be a substantial disconnect between the intended curriculum and the received curriculum in inclusive classrooms. We did not document the extent to which students received high-quality instructional methods and materials, nor did we inquire about how and whether instruction in self-determination was adapted, altered, or enhanced for students with 
disabilities. Clearly, the quality of instruction matters as much as-if not more than-the frequency of addressing a skill. Mason et al. (2004) found that self-determination skills typically are taught somewhat informally, with limited direct instruction. Students with disabilities may need much more explicit, systematic, and applied instruction to acquire some self-determination skills (Eisenman, 2007; Field \& Hoffman, 2002). Future research should document specific approaches to teaching skills that promote self-determined behavior in general education classrooms, as well as the strategies educators use to adapt, augment, and alter the curriculum to help youth with disabilities access these critical learning opportunities.

\section{IMPLICATIONS FOR PRACTICE}

General education classrooms-both academic and elective-may provide ample opportunities for students with disabilities to acquire skills that may enhance their self-determination. The challenge remains for educators to identify effective strategies that fully capitalize on these opportunities so that students with disabilities are able to acquire and fluently apply those skills (e.g., Konrad, Trela, \& Test, 2006; Wehmeyer et al., 2004). Palmer et al. (2004) described one promising model-the Self-Determined Learning Model of Instruction-for promoting both self-determination and access to the general curriculum. This model involves a multilevel, scaffolded approach for teaching students self-directed learning strategies (e.g., problem solving, goal setting, self-evaluation) that enable them to engage more meaningfully in instructional experiences available through the general curriculum.

\section{Students with disabilities may need much more explicit, systematic, and applied instruction to acquire some self-determination skills.}

Recent research syntheses also have described effective strategies for increasing skills related to self-determination, including self-advocacy (Test, Fowler, Brewer, et al., 2005); choice making
(Cannella, O'Reilly, \& Lancioni, 2005; Shogren, Faggella-Luby, Bae, \& Wehmeyer, 2004); selfmanagement (Mooney, Ryan, Uhing, Reid, \& Epstein, 2005; Reid, Trout, \& Schwartz, 2005); and problem solving (e.g., Algozzine, Browder, Karvonen, Test, \& Wood, 2001). However, these intervention strategies typically have been evaluated (a) in self-contained or specialized settings, and (b) with a narrow subset of specific disability categories (e.g., intellectual disabilities, learning disabilities). There remains a pressing need for intervention and instructional strategies that are feasible, effective, and relevant in general education classrooms at the high school level, as well as strategies that work for a broad range of students. Therefore, educators should couple strategy use with careful data collection and progress monitoring to ensure that students are benefiting maximally from instructional efforts directed at this area.

\section{LIMITATIONS}

Several limitations to this study suggest areas for future research. First, our findings were based on educators' self-reports of instructional priorities and practices, introducing the potential for social desirability in ratings. Observational methods have remained largely absent from self-determination research involving students with disabilities. Divergent-and sometimes discrepant-perceptions of self-determination skills and opportunities highlight the importance of coupling indirect assessments (e.g., surveys, interviews) with direct observations. Indeed, the development of a reliable and valid observational technology for assessing both instructional opportunities and self-determined behavior would greatly enhance the ability of researchers to conduct more finegrained analyses of the relation between students' educational experiences and self-determination.

Second, although some differences were noted for teacher type and curricular area, we were able to account for a relatively small proportion of the variance in educators' ratings of selfdetermination importance and instruction. Additional research is needed to identify other factors that may influence students' opportunities for developing skills that enhance self-determination (c.f., Carter et al., 2006; Shogren et al., 
2007; Wehmeyer et al., 2000). Potential factors might include teacher variables (e.g., years of experience, professional development opportunities); student variables (e.g., disability category, disability severity, gender, age); or school variables (e.g., risk status, service delivery models).

Third, we did not explore the specific instructional or curricular strategies that educators used to teach various self-determination skills in their classrooms. Future research should incorporate open-ended avenues through which educators could contribute detailed examples of how they infuse self-determination instruction within the curriculum. Hughes et al. (1997) outlined one promising method for capturing such qualitative information from multiple stakeholders. Related tactics would expand our understanding of promising approaches that are both tractable and acceptable to practitioners. Finally, we focused narrowly on efforts to promote self-determination at the high school level; the importance of addressing self-determination at an earlier age has been a recurring theme throughout the self-determination literature (Eisenman \& Chamberlin, 2001; Sands \& Doll, 1996). Future research should examine the efforts of elementary and middle school educators to enhance students' capacities to engage in self-determined behavior.

\section{There remains a pressing need for intervention and instructional strategies that are feasible, effective, and relevant in general education classrooms at the high school level, as well as strategies that work for a broad range of students.}

We are hopeful that secondary educators will increase their responsiveness to researchers' calls to expand students' opportunities to become more self-determined (Carter et al., 2006; Mithaug, Mithaug, Agran, Martin, \& Wehmeyer, 2003). Of primary concern, however, is whether acquisition of these various component skills contribute to greater self-determination and, ultimately, improved postschool outcomes. As this line of research continues to evolve, additional attention should be focused on identifying evidence-based practices for promoting self-determined behavior in general education contexts.

\section{REFERENCES}

Agran, M., Snow, K., \& Swaner, J. (1999). Teacher perceptions of self-determination: Benefits, characteristics, and strategies. Education and Training in Mental Retardation and Developmental Disabilities, 34, 293-301.

Algozzine, B., Browder, D., Karvonen, M., Test, D. W., \& Wood, W. M. (2001). Effects of interventions to promote self-determination for individuals with disabilities. Review of Educational Research, 71, 219-277.

Alwell, M., \& Cobb, B. (2006). A map of the intervention literature in secondary special education transition. Career Development for Exceptional Individuals, 29, 3-27.

Bremer, C. D., Kachgal, M., \& Schoeller, K. (2003). Self-determination: Supporting successful transition. Research to Practice Brief, 2(1), 1-6.

Cameto, R., Levine, P., Wagner, M., \& Marder, C. (2003). The emerging independence of youth with disabilities. In M. Wagner et al. (Eds.), The achievements of youth with disabilities during secondary school (pp. 6.1-6.22). Menlo Park, CA: SRI International.

Cannella, H. I., O'Reilly, M. F., \& Lancioni, G. E. (2005). Choice and preference assessment research with people with severe to profound developmental disabilities: A review of the literature. Research in Developmental Disabilities, 26, 1-15.

Carter, E. W., \& Hughes, C. (2006). Including high school students with severe disabilities in general education classes: Perspectives of general and special educators, paraprofessionals, and administrators. Research and Practice for Persons With Severe Disabilities, 31, 174-185.

Carter, E. W., Lane, K. L., Pierson, M., \& Glaeser, B. (2006). Self-determination skills of transition-age youth with emotional disturbances and learning disabilities. Exceptional Children, 72, 333-346.

Chambers, C. R., Wehmeyer, M. L., Saito, Y., Lida, K. M., Lee, Y., \& Singh, V. (2007). Self-determination: What do we know? Where do we go? Exceptionality, 15, 3-15.

Council for Exceptional Children (2003). What every special educator must know: Ethics, standards, and guidelines for special educators (5th ed.). Arlington, VA: Author.

Eisenman, L. T. (2007). Self-determination interventions: Building a foundation for school completion. Remedial and Special Education, 28, 2-8. 
Eisenman, L. T., \& Chamberlin, M. (2001). Implementing self-determination activities: Lessons from schools. Remedial and Special Education, 22, 138-147.

Eisenman, L. T., \& Tascione, L. (2002). "How come nobody told me?" Fostering self-realization through a high school English curriculum. Learning Disabilities Research of Practice, 17, 35-46.

Field, S., \& Hoffman, A. (2002). Preparing youth to exercise self-determination: Quality indicators of school environments that promote the acquisition of knowledge, skills, and beliefs related to self-determination. Journal of Disability Policy Studies, 13, 113-118.

Field, S., Sarver, M. D., \& Shaw, S. F. (2003). Self-determination: A key to success in postsecondary education for students with learning disabilities. Remedial and Special Education, 24, 339-349.

Field, S. S., Martin, J. E., Miller, R. J., Ward, M., \& Wehmeyer, M. L. (1998). Self-determination for persons with disabilities: A position statement of the Division on Career Development and Transition. Career Development for Exceptional Individuals, 21, 113-128.

Grigal, M., Neubert, D. A., Moon, M. S., \& Graham, S. (2003). Self-determination for students with disabilities: Views of parents and teachers. Exceptional Children, 70, 97-112.

Houchins, D. E. (2002). Self-determination knowledge instruction and incarcerated students. Emotional and Behavioural Difficulties, 7, 132-151.

Hughes, C., Kim, J., Hwang, B., Killian, D. J., Fischer, G. M., Brock, M. L., et al. (1997). Practitioner-validated secondary transition support strategies. Education and Training in Mental Retardation of Developmental Disabilities, 32, 201-212.

Kleinbaum, D. G., Kupper, L. L., Muller, K. E., \& Nizam, A. (1998). Applied regression analysis and other multivariable methods (3rd ed.). Belmont, CA: Brooks/Cole.

Kochhar-Bryant, C. A., \& Bassett, D. S. (Eds.). (2002). Aligning transition and standards-based education: Issues and strategies. Arlington, VA: Council for Exceptional Children.

Konrad, M., Trela, K., \& Test, D. W. (2006). Using IEP goals and objectives to teach paragraph writing to high school students with physical and cognitive disabilities. Education and Training in Developmental Disabilities, 41, 111-124.

Kortering, L., Braziel, P., \& Tompkins, J. (2002). The challenge of school completion among youth with behavior disorders: Another side of the story. Behavioral Disorders, 27, 142-154.
Lachapelle, Y., Wehmeyer, M. L., Haelewyck, M. C., Courbois, Y., Keith, K. D., Schalock, R., et al. (2005). The relationship between quality of life and self-determination: An international study. Journal of Intellectual Disability Research, 49, 740-744.

Lane, K. L., \& Carter, E. W. (2006). Supporting transition-age youth with and at risk for emotional and behavioral disorders at the secondary level: A need for further inquiry. Journal of Emotional and Behavioral Disabilities, 14, 66-70.

Lane, K. L., Pierson, M. R., \& Givner, C. C. (2004). Secondary teachers' views on social competence: Skills essential for success. The Journal of Special Education, 38, 174-186.

Lane, K. L., Wehby, J. H., \& Robertson, E. J. (2007). Studying school-wide positive behavior support at the high school level: A formidable task. Manuscript submitted for publication.

Maccini, P., \& Gagnon, J. C. (2006). Mathematics instructional practices and assessment accommodations by secondary special and general educators. Exceptional Children, 72, 217-234.

Malian, I., \& Nevin, A. (2002). A review of self-determination literature: Implications for practitioners. Remedial and Special Education, 23, 68-74.

Martin, J. E., Van Dycke, J. L., Greene, B. A., Gardner, J. E., Christensen, W. R., Woods, L. L., et al. (2006). Direct observation of teacher-directed IEP meetings: Establishing the need for student IEP meeting instruction. Exceptional Children, 72, 187-200.

Mason, C., Field, S., \& Sawilosky, S. (2004). Implementation of self-determination activities and student participation in IEPs. Exceptional Children, 70, $441-451$.

Mithaug, D. E., Campeau, P. L., \& Wolman, J. M. (2003). Assessing self-determination prospects among students with and without disabilities. In D. E. Mithaug, D. Mithaug, M. Agran, J. Martin, \& M. L. Wehmeyer (Eds.), Self-determined learning theory: Construction, verification, and evaluation (pp. 61-76). Mahwah, NJ: Lawrence Erlbaum.

Mithaug, D. E., Mithaug, D., Agran, M., Martin, J., \& Wehmeyer, M. L. (Eds.). (2003). Self-determined learning theory: Construction, verification, and evaluation. Mahwah, NJ: Lawrence Erlbaum.

Mooney, P., Ryan, J. B., Uhing, B. M., Reid, R., \& Epstein, M. H. (2005). A review of self-management interventions targeting academic outcomes for students with emotional and behavioral disorders. Journal of Behavioral Education, 14, 303-331. 
National Board for Professional Teaching Standards. (1999). NBPTS exceptional needs standards for teachers of students ages birth-21+. Arlington, VA: Author.

Palmer, S. B., Wehmeyer, M. L., Gipson, K., \& Agran, M. (2004). Promoting access to the general curriculum by teaching self-determination skills. Exceptional Children, 70, 427-439.

Pocock, A., Lambros, S., Karvonen, M., Test, D. W., Algozzine, B., Wood, W., et al. (2002). Successful strategies for promoting self-advocacy among students with LD: The LEAD group. Intervention in School and Clinic, 37, 209-216.

Reid, R., Trout, A. L., \& Schwartz, M. (2005). Selfregulation interventions for children with attention deficit/hyperactivity disorder. Exceptional Children, 71 , 361-377.

Sands, D. J., \& Doll, B. (1996). Fostering self-determination is a developmental task. The Journal of Special Education, 30, 58-76.

Shogren, K. A., Faggella-Luby, M. N., Bae, S. J., \& Wehmeyer, M. L. (2004). The effect of choice-making for problem behavior: A meta-analysis. Journal of Positive Behavioral Interventions, 6, 228-237.

Shogren, K. A., Wehmeyer, M. L., Palmer, S. B., Soukup, J. H., Little, T. D., Garner, N., et al. (2007). Examining individual and ecological predictors of the self-determination of students with disabilities. Exceptional Children, 73, 488-509.

Snyder, T. D., Dillow, S. A., \& Hoffman, C. M. (2007). Digest of education statistics: 2006. Washington, DC: National Center for Education Statistics.

Test, D. W., Fowler, C. H., Brewer, D. M., \& Wood, W. M. (2005). A content and methodological review of self-advocacy intervention studies. Exceptional Children, 72, 101-125.

Test, D. W., Fowler, C. H., Wood, W. M., Brewer, D. M., \& Eddy, S. (2005). A conceptual framework of self-advocacy for students with disabilities. Remedial and Special Education, 26, 43-54.

Test, D. W., Mason, C., Hughes, C., Konrad, M., Neale, M., \& Wood, W. M. (2004). Student involvement in individualized education program meetings. Exceptional Children, 70, 391-412.

Thoma, C. A., Nathanson, R., Baker, S. R., \& Tamura, R. (2002). Self-determination: What do special educators know and where do they learn it? Remedial and Special Education, 23, 242-247.

Trainor, A. (2005). Self-determination perceptions and behaviors of diverse students with LD during the transition process. Journal of Learning Disabilities, 38, 233-249.
U.S. Department of Education. (2006). Twenty-sixth annual report to Congress on the implementation of the Individuals With Disabilities Education Act, 2004. Washington, DC: Author.

Van-Belle, J., Marks, S., Martin, R., \& Chun, M. (2006). Voicing one's dreams: High school students with developmental disabilities learn about self-advocacy. TEACHING Exceptional Children, 38(4), 40-46.

Wagner, M., Newman, L., \& Cameto, R. (2004). Changes over time in the secondary school experiences of students with disabilities: $A$ report of findings from the National Longitudinal Transition Study (NLTS) and the National Longitudinal Transition Study-2 (NLTS2) Menlo Park, CA: SRI International.

Wagner, M., Newman, L., Cameto, R., Levine, P., \& Marder, C. (2003). Going to school: Instructional contexts, programs, and participation of secondary school students with disabilities: A report from the National Longitudinal Transition Study-2 (NLTS2). Menlo Park, CA: SRI International.

Wehmeyer, M. L., Agran, M., \& Hughes, C. (2000). A national survey of teachers' promotion of self-determination and student-directed learning. The Journal of Special Education, 34, 58-68.

Wehmeyer, M. L., \& Field, S. (2007). Instructional and assessment strategies to promote the self-determination of students with disabilities. Thousand Oaks, CA: Corwin Press.

Wehmeyer, M. L., Field, S., Doren, B., Jones, B., \& Mason, C. (2004). Self-determination and student involvement in standards-based reform. Exceptional Children, 70, 413-425.

Wehmeyer, M. L., \& Palmer, S. B. (2003). Adult outcomes for students with cognitive disabilities three years after high school: The impact of self-determination. Education and Training in Developmental Disabilities, 38, 131-144.

Wehmeyer, M. L., \& Schwartz, M. (1997). Self-determination and positive adult outcomes: $A$ follow-up study of youth with mental retardation or learning disabilities. Exceptional Children, 63, 245-255.

Wehmeyer, M. L., \& Schwartz, M. (1998). The relationship between self-determination and quality of life for adults with mental retardation. Education and Training in Mental Retardation and Developmental Disabilities, 33, 3-12.

Whitney-Thomas, J., \& Moloney, M. (2001). "Who I am and what I want": Adolescents' self-definition and struggles. Exceptional Children, 67, 375-389.

Zhang, D. (2001). Self-determination and inclusion: Are students with mild mental retardation more self- 
determined in regular classrooms? Education and Training in Mental Retardation and Developmental Disabilities, 36, 357-362.

Zhang, D., Wehmeyer, M. L., \& Chen, L. (2005). Parent and teacher engagement in fostering the self-determination of students with disabilities: A comparison between the United States and the Republic of China. Remedial and Special Education, 26, 55-64.

\section{ABOUT THE AUTHORS}

ERIK W. CARTER (CEC WI Federation), Assistant Professor, Rehabilitation Psychology and Special Education, School of Education, University of Wisconsin-Madison. KATHLEEN L. LANe (CEC TN Federation), Assistant Professor of Special Education, Peabody College, Vanderbilt University, Nashville, Tennessee. MELINDA R. PIERson (CEC CA Federation), Professor; and Kristin K. STANG (CEC CA Federation), Assistant Professor, College of Education, California State University, Fullerton.
Address correspondence to Erik W. Carter, Rehabilitation Psychology and Special Education Department, University of Wisconsin-Madison, 432 Ease Campus Mall, Madison, WI 53706 (e-mail: ewcarter@wisc.edu).

Manuscript received May 2007; accepted August 2007. 
Copyright of Exceptional Children is the property of Council for Exceptional Children and its content may not be copied or emailed to multiple sites or posted to a listserv without the copyright holder's express written permission. However, users may print, download, or email articles for individual use. 